\title{
Rethink the interlink between land degradation and livelihood of rural communities in Chilga district, Northwest Ethiopia
}

Kassahun Gashu ${ }^{1 *}$ (D) and Yitbarek Muchie ${ }^{2}$

\begin{abstract}
Background: Ethiopia is among the poorest countries where land degradation caused livelihood problem to its inhabitants. The livelihood of rural communities in Ethiopia is seriously threatened by land degradation. Land is the major natural resource that economic, social, infrastructure, and other human activities are undertaken on. Thus, land resources play an important role in shaping rural livelihoods, and lack of sustainable land management practices leads to land degradation. Thus, this study aimed to analyze interlink between land degradation and livelihood of rural communities in Chilga district, Northwest Ethiopia. It also addresses the factors which influence income diversification for livelihood of households in the study area.
\end{abstract}

Result: The result depicts that the major causes of land degradation are both natural and anthropogenic. Land degradation and livelihood are negatively interlinked with each other. The livelihood of the majority of the population in the study area is dependent on subsistence agriculture both farming and animal husbandry with low diversification. The survey result showed that more than half (69\%) of the sample households have farm size of less than 2 ha, nearly one third (31\%) have 2.0-2.5 ha, and insignificant number of farmers have more than 2.5 ha. More than $80 \%$ of the respondents pointed out that land degradation has impacts both on crop yield and livestock production. Most of the explanatory variables such as gender, age, education level, farmland size, and family size have statistical significant influence (at $P<.01$ and $P<.05$ levels) for income diversification of households, while marital status on the other hand is not statistically significant though it has positive relation with income diversification in this study.

Conclusions: Our results suggest awareness should be created in the community about the livelihood diversification mechanisms which enabled them to engage in different income-generating activities and comprehensive watershed management should be implemented.

Keywords: Chilga district, Income diversification, Land degradation-livelihood nexus, Livelihood strategies, Northwest Ethiopia

\footnotetext{
*Correspondence: Kg19me@gmail.com

${ }^{1}$ Department of Geography and Environmental Studies, University of Gondar,

P.O. Box 196, Gondar, Ethiopia

Full list of author information is available at the end of the article
}

(c) The Author(s). 2018 Open Access This article is distributed under the terms of the Creative Commons Attribution 4.0 International License (http://creativecommons.org/licenses/by/4.0/), which permits unrestricted use, distribution, and reproduction in any medium, provided you give appropriate credit to the original author(s) and the source, provide a link to the Creative Commons license, and indicate if changes were made. The Creative Commons Public Domain Dedication waiver (http://creativecommons.org/publicdomain/zero/1.0/) applies to the data made available in this article, unless otherwise stated. 


\section{Background}

The East African region where Ethiopia is located is one of the world's most food-insecure regions with increasing human population growth which is highly dependent on natural resource base for their livelihood (Pricope et al. 2013). Ethiopia is one of the most highly populated countries in Africa with about 100 million people (CSA 2017). Land is one of the most important natural resources. However, land degradation is an important problem in Ethiopia, with more than $85 \%$ of the land degraded to various degrees. Only about $51 \%$ of land degradation represents the loss of providing ecosystem services. The remaining 49\% represents the loss of supporting and regulatory and cultural ecosystem services (Gebreselassie et al. 2016).

Land degradation is a continuous process (Hurni 1993; Bewket 2003; Sivakumar and Ndiangui 2007) and has become, however, an important concern affecting food security and the wealth of nations and has an impact on the livelihood of almost every person on this earth (Bizuayehu et al. 2002). Land degradation is thought to be especially widespread throughout sub-Saharan Africa (Darkoh 1993; MoARD 2010). Land degradation has the highest effect on the livelihoods and well-being of the poorest households in the rural areas of developing countries (Nachtergaele et al. 2010). Land degradation in most developing countries is becoming a major constraint to future growth and development (Reddy 2003; Hammad and Tumeizi 2012). Among Sub-Saharan countries, Ethiopia is the most seriously affected country by land degradation (Shiferaw and Holden 1998; Amsalu 2006).

The Global Mechanism (2007) estimated that over $85 \%$ of the land in Ethiopia is moderately to very severely degraded and about $75 \%$ is affected by desertification. The most common form of land degradation in Ethiopia is soil erosion by water. Rain-fed agriculture employs $80 \%$ of the population, forming the basis of Ethiopia's economy. Environmental degradation, as exhibited in land and water resources' degradation together with biodiversity loss, remains a key development challenge for the Ethiopian agriculture (Gebreselassie et al. 2016). Many findings depict that the highlands of northwestern Ethiopia are highly vulnerable to land degradation. Indeed, the degradation of land to be severe in the highlands of northern Ethiopia is related with early human settlements and age-old farming activities vis-à-vis the southern part. Historically, the civilization of Ethiopia had begun in the northern part, and hence, it had been the place of human settlement and farming for thousands of years ago (Hurni 1990). In Ethiopia, natural resource is in the state of serious degradation: the problem manifests itself in the form of soil and water degradation and loss of biodiversity (Amsalu and de Graaff 2006).

Land cultivation is the main livelihood of the farming community members that constitute $85 \%$ of the Ethiopian population (Amsalu and DeGraaff 2007). Hence, land degradation is a serious problem that affects land productivity and threatens the livelihoods of the majority of Ethiopia's population (WFP 2005). Empirical studies depict that land degradation has a great impact on the livelihood of rural communities who depend on primary economic activities mainly agriculture and it has also impact on the national GDP of Ethiopia (FAO 1986; Bojö and Cassells 1995; Sonneveld 2002; Berry 2009). Land degradation affects those communities whose livelihood depends on land resources, and the type of economic activity of the people has also influence on land degradation process (Limeneh 2004). Land degradation has a far-reaching consequence on the livelihood of rural communities who are tied with land resources. Land degradation results in food insecurity, poverty, and out-migration for those rural communities whose livelihood depends on land resources.

The link between livelihood and land degradation is said to be a symbiotic relationship in a form of a vicious cycle. It is considered an upward spiral in which causality runs both ways. Hence, livelihood improvement should be tackled alongside the control of land degradation. In Ethiopia as well as other developing countries, land degradation is a major problem due to the agrarian nature of their economy. Many African countries (70\%), e.g., Ghana and Ethiopia, depend on the land for their livelihoods (Peprah 2014). The fundamental importance of land extends to dependence on food, fiber, fuel, and general ecosystem provisions of fresh air (oxygen), water, and climate regulation. So far, ample empirical studies were not conducted at the study area to analyze the interlink between livelihood and land degradation nexus. Therefore, the aim of this study is to examine interlinks between land degradation and livelihood in order to come up with appropriate interventions that could help the efforts of rural communities. Moreover, this study tries to address the factors that affect income diversification of households' for their livelihood.

\section{Conceptual framework}

Land degradation is a major global issue for the twentieth century and will remain high on the international agenda even for the twenty-first century too (Gashaw et al. 2014). Scholars identified different causes of land degradation. For example, according to Berry (2003), the cause of land degradation involves two interlocking complex systems: the natural ecosystem and the anthropogenic or human social system. Interactions between the two systems determine the success or failure of resource management. Land degradation is caused by human-induced or natural processes which negatively affect the capacity of land to function effectively within an ecosystem. When examining the role of land degradation in the agriculture 
and environment nexus, it is essential to understand the human-induced impact on the productive capacity of the land. However, the relationship between livelihood and land degradation is far more complex (Tengberg and Torheim 2007).

This section presents the interlinkage between livelihood and land degradation based on the preceding theoretical literature discussions above. Hence, a conceptual framework is developed as a guiding tool to a better understanding of land degradation and livelihood nexus (Fig. 1).

At the outset, farmer's awareness about land degradation determines the drivers or causes of land degradation. These drivers or causes led to land degradation to occur, and it has an impact on the livelihoods of the people. The different livelihood mechanisms of households determine their life to be whether better or bad.

\section{Methods}

\section{The study area}

Chilga district is located in northwestern Ethiopia in North Gondar administrative zone, Amhara regional state, at a distance of $61 \mathrm{~km}$ and $236 \mathrm{~km}$ from the zonal town and regional capital Gondar and Bahir Dar respectively. The district has a total of 44 rural peasant associations and one town administration. The district is located between $13^{\circ} 82^{\prime} 00^{\prime \prime} \mathrm{N}$ to $13^{\circ} 88^{\prime} 00^{\prime \prime} \mathrm{N}$ latitude and $27^{\circ} 28^{\prime} 00^{\prime \prime} \mathrm{E}$ to $28^{\circ} 48^{\prime} 00^{\prime \prime}$ E longitude.

The altitude of the study area ranges from 1200 to $1770 \mathrm{~m}$ above sea level. The topographic condition of the study area is characterized by having rugged mountains. It is generally characterized more or less by having up and down landscapes. According to the Chilga district agricultural office, the climatic condition of the district is categorized under Kolla (67\%) and woina dega (33\%) agro-climatic zones. The mean annual minimum and maximum rainfall of the area ranges from 1200 to $1500 \mathrm{~mm}$ respectively. The study area is characterized by having uni-modal rainfall distribution. More than $75 \%$ of the total rainfall and the highest rainfall occur in July (CWAO 2015).

The mean annual minimum and maximum temperature of the area ranges from 20 to $25{ }^{\circ} \mathrm{C}$ respectively. The warmest months of the area are between February and May. On the contrary, the coldest months of the study area range between June and August (NMA 2015). According to CWAO (2015), the district has different soil types. Of these, $45 \%$ is brown soil, $40 \%$ black soil (vertisols), and 15\% red soil (nitosols). The majority of the study area is dominated with soils of brown color. With respect to the composition of soil texture of the study area, sand soil (leptosols) dominates the area followed by clay (vertisols) and silt (nitosols). Hence, many soil types exhibit a general relationship with altitude and slopes of the area. The area is mountainous, hilly, and up-down laying slope; because of this, soil erosion has made cultivation infeasible in the several parts of the watershed. Regarding the landholding of farmers in the study area, as to most of the highlands of the country, it is characterized as very small. There is a significant variation in the size of landholding

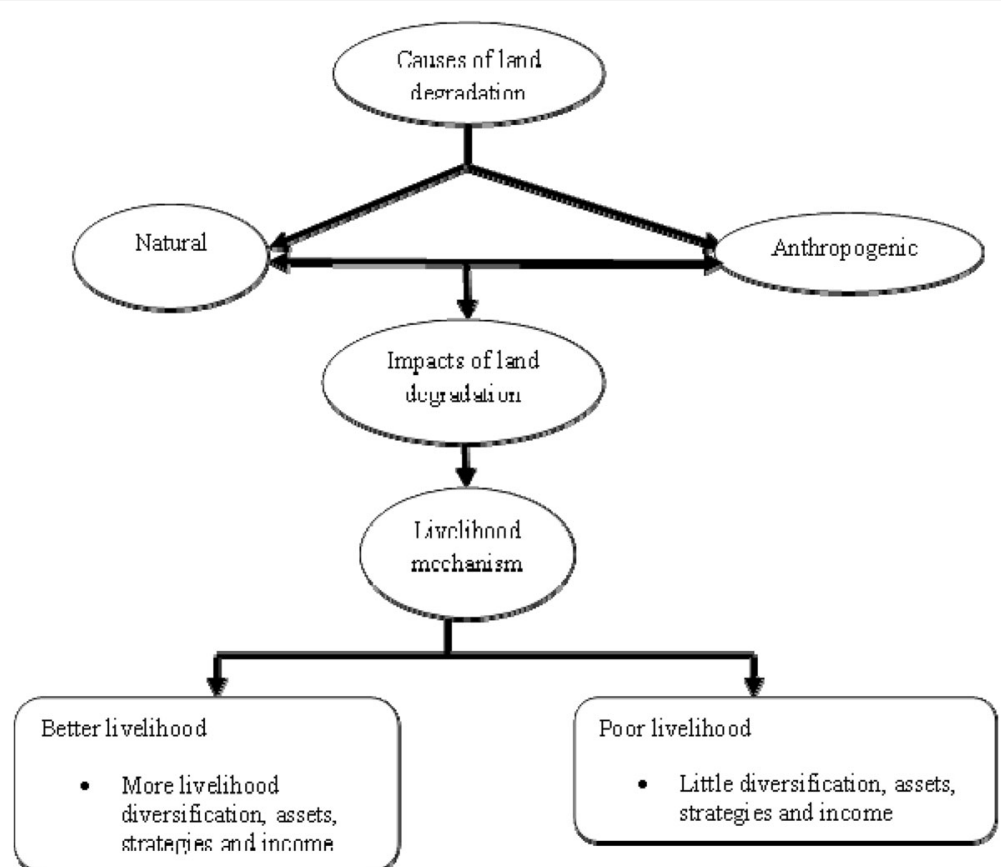

Fig. 1 Conceptual framework of land degradation-livelihood nexus 
among households. The minimum and maximum sizes of landholding were 0.25 ha and 3 ha, respectively, the average being 1.6 ha (CWAO 2015). The majority of farmers in the study area cultivate less than 2 ha of land, which is insufficient to support their family members.

\section{Data}

This study was descriptive-survey research design. The study uses both primary and secondary sources of data. The primary data is obtained via field visit, FGD, and interview and survey questionnaire. Secondary data were collected from annual reports and published and unpublished literature.

Survey questionnaire was prepared in Amharic languages so as to minimize the language barrier for the local community and converted to English language during analysis. The FGD was carried out with six members each with three groups in different locations. The participants of the FGD were identified, and the time and place of discussion was arranged based on the consensus of the participants. Hence, the participants agreed that the discussion should be held on Sunday because they reason out that other days are working days and market days. The discussion was conducted for $1 \mathrm{~h}$ for each group. The participants of the discussion were mainly development agents in the area, elders, and women. Hence, the FGD reveals how people discuss certain topics as members of a group, not just as individuals. Both structured and unstructured interviews were prepared for the peasant association leaders. Moreover, interview with key informant mainly with the head of the district agricultural office was conducted.

\section{Sampling technique and sample size determination}

The study district and the sample peasant association (Waldiba peasant association) were selected purposively based on the researchers' prior knowledge. There are a total of 500 household heads in the sample peasant association (CWAO 2015). The total sample size from the selected peasant association can be determined using Kothari (2004) formula as follows:

$$
n=\frac{z^{2} \times p \times q \times N}{e^{2}(N-1)+z^{2} \times q \times p}
$$

where $n$ is the sample size, $z$ is the values of standard variation at $95 \%$ confidence interval (1.96), $p$ is the estimated proportion of households affected by land degradation (0.03), $q$ is $1-p, e$ is the standard error (acceptable error) which should be within $3 \%$ of the true value, and $N$ is the number of total household heads in the sample peasant association.

Hence, $\quad n=(1.96)^{2} \times 0.03 \times 0.97 \times 500 /(0.03)^{2}(500-1)$ $+(1.96)^{2} \times 0.97 \times 0.03=99.6 \approx 100$.
In order to include both male and female household heads, proportional sampling technique using the following formula was used: $\mathrm{ni}=\left[\frac{\mathrm{Ni}}{N}\right] \times n$, where ni is the sample size of male and/or female household heads, $\mathrm{Ni}$ is the number of male or female household heads, $N$ is the total number of household heads in the sample peasant association, and $n$ is the total sample size.

There are 425 male-headed households and 75 female-headed households (CWAO 2015) in the study area (Table 1). Of the total population of the study area, $20 \%$ was taken as a sample. Individual household head samples were chosen using simple random sampling technique.

\section{Data analysis}

The study employed both qualitative and quantitative methods of data analysis. Descriptive statistics (mean, percentage) was used to summarize key variables. Besides this, Pearson correlation coefficient and binary logistic regressions were employed to show the relationships and influence of explanatory variables (gender of household head, age of household head, educational level of household head, marital status of household head, family size of household and landholding size of household head) on the dependent variable income of household for livelihood diversification (Table 2).

The pattern of association between the response and explanatory variables was assessed by Pearson's correlation, which was also used to evaluate the presence or absence of multicollinearity among the explanatory variables. The model used for this analysis is:

$$
\mathrm{Yi}=a+b_{1} x_{1}+b_{2} x_{2}+\ldots+b_{6} x_{6}
$$

where $\mathrm{Yi}$ is the dependent variable (perception towards green infrastructure), $a$ is the regression constant ( $Y$-intercept), $b_{1-}{ }_{6}$ are the slope of the regression line (are coefficients indicating the degree of association between each independent variable and the outcome), and $x_{1-6}$ are the independent variables.

\section{Results}

\section{Socio-economic background of the respondents}

The survey result depicts that from the total of 100 samples household farmers $85 \%$ were males and $15 \%$ were females with a maximum age of 70 years, a minimum age of 20 years, and an average age of 45 years (Table 3).

Table 1 Sample size of households

\begin{tabular}{lll}
\hline Gender & $\mathrm{NHHH}$ & Sample size \\
\hline Male headed & 425 & $425 \times 20 / 100=85$ \\
Female headed & 75 & $75 \times 20 / 100=15$ \\
Total & 500 & $500 \times 20 / 100=100$ \\
\hline
\end{tabular}

$\mathrm{NHHH}$ number of household heads 
Table 2 Description of dependent and explanatory variables

\begin{tabular}{|c|c|c|}
\hline Variables specified in the model & Variable's definition & $\mathrm{EDI}( \pm)$ \\
\hline INCM (income of household) & $\begin{array}{l}\text { INCM was assigned a value of " } 1 \text { ", if a household head has good } \\
\text { income for his/her livelihood and " } 0 \text { " if not. }\end{array}$ & \\
\hline$X_{1}=$ GEN (gender of a household head) & $\begin{array}{l}\text { GEN was assigned a value of " } 1 \text { ", if a household head is male } \\
\text { and " } 0 \text { " otherwise. }\end{array}$ & + \\
\hline$X_{2}=$ AGE (age of a household head) & $\begin{array}{l}\text { AGE was given in years. Age is considered to be important since } \\
\text { a person may increase his/her perception (e.g., knowledge of land } \\
\text { degradation) as he/she gets older. A value of "1" was given if the } \\
\text { age of the household head was }>30 \text { years, and a value of " } 0 \text { " was } \\
\text { given if the age of the household head was } \leq 30 \text { years. }\end{array}$ & + \\
\hline$X_{3}=$ EDUCL (education Level of a household head) & $\begin{array}{l}\text { EDUCL was measured using the attainment of grade levels by the } \\
\text { respondent. Education helps to raise perception level about income } \\
\text { diversification for livelihood. A value of "1" was given if the educational } \\
\text { status of the household head was primary school (grades 1-8) } \\
\text { completed and "0" uneducated }\end{array}$ & + \\
\hline$X_{4}=$ MRS (marital status of household head) & $\begin{array}{l}\text { MRS was marital status of the household head. A value of "1" was } \\
\text { given if a household head was legally married and "0" otherwise. }\end{array}$ & + \\
\hline$X_{5}=$ FMS (family size) & $\begin{array}{l}\text { FMS measures the number of members of a family under one roof. } \\
\text { A value of " } 1 \text { " was given if the family size is }>5 \text { and " } 0 \text { " if the family } \\
\text { size is } \leq 5\end{array}$ & - \\
\hline$X_{6}=$ LHS (landholding size of household head) & $\begin{array}{l}\text { LHS measures the landholding size of the household head. An average } \\
\text { landholding size is expected to be } 0.5 \text { ha. A value of " } 1 \text { " was given if a } \\
\text { household head owns }>0.5 \text { ha and " } 0 \text { " if the household head } \\
\text { owns } \leq 0.5 \text { ha. }\end{array}$ & + \\
\hline
\end{tabular}

This indicated that majority of sampled household age is between 34 and 49 years, and hence, they are in an economically active age group assumed to have good income and livelihood diversity.

Majority of the sample household heads are married (75\%), and only a few are either divorced or widowed (Table 3). The average family size of the sample households is 6.6. This implies that there is a high population density in the study area which is more than the national average 4.6 (CSA 2016). This high population density has its own great role for aggravating land degradation problem. Most of the sample household head farmers have neither read nor write educational level (69\%) while a few are either primary or secondary education level.

The survey result showed that more than half (69\%) of the sample households have farm size of $<2$ ha, nearly one third (31\%) have 2.0-2.5 ha, and insignificant number of farmers have more than 2.5 ha. Based on the data obtained from the survey, the average farm size of the households in the study area is 1.6 ha.

\section{Impact of land degradation on livelihood}

With regard to the impact of land degradation on the livelihood of rural communities in the study area, the survey result showed that $100 \%$ of the respondents (Table 4) replied that land degradation has a great impact on their livelihood. Eighty-three percent of the respondents (Table 4) pointed out that land degradation has impacts both on crop yield and livestock production. This is also supported by the FGD discussants who disclosed there is a declining trend in both crop and livestock production because of the impact of land degradation. In terms of agricultural productivity, they also explained that they used different agricultural inputs to increase their production; however, their yield could not cover their debt and expenditure, whereas in terms of livestock production, they also expressed that in the former time a single individual can possess 20 to 30 heads of cattle in the area and currently majority of the people have 1 or 2 heads of cattle. According to the local social classification, those households, who have 2 and above oxen can be considered as rich; however, a significant number of households in the study area have a single ox and have no ox. Those households that have a single ox make a sharing with those households that have single locally called kanja and plough their farmland. On the contrary, those households that have no oxen are compelled to sharecrop to those who have oxen to plough their farmland.

Concerning the level of impact of land degradation on their livelihood, all of the respondents responded that the impact of land degradation on their livelihood is either serious or noticeable. Hence, it is understood that the impact of land degradation on the livelihood of rural communities in the study area is serious (Table 4).

The survey result depicts that $100 \%$ (Table 4) of the respondents replied that there is a change in crop production due to land degradation. Regarding the reason for the decline in crop production, the possible reasons for the decline in crop production are loss of soil fertility 
Table 3 Socio-demographic characteristics of respondents

\begin{tabular}{|c|c|}
\hline Attributes & Frequency \\
\hline \multicolumn{2}{|l|}{ Gender (\%) } \\
\hline Male & 85 \\
\hline Female & 15 \\
\hline \multicolumn{2}{|l|}{ Age (years) } \\
\hline Minimum & 20 \\
\hline Maximum & 70 \\
\hline Average & 45 \\
\hline \multicolumn{2}{|l|}{ Marital status } \\
\hline Married & 75 \\
\hline Single & 01 \\
\hline Divorced & 12 \\
\hline Widowed & 12 \\
\hline \multicolumn{2}{|l|}{ Family size (number) } \\
\hline $1-3$ & 19 \\
\hline $4-6$ & 32 \\
\hline $7-9$ & 26 \\
\hline$>10$ & 23 \\
\hline \multicolumn{2}{|l|}{ Educational status } \\
\hline Cannot read and write & 69 \\
\hline Basic education & 21 \\
\hline Primary education & 9 \\
\hline Secondary education & 10 \\
\hline \multicolumn{2}{|l|}{ Landholding size (hectares) } \\
\hline$\leq 0.5$ & 19 \\
\hline $0.6-1.5$ & 17 \\
\hline $1.6-2.0$ & 33 \\
\hline $2.1-2.5$ & 23 \\
\hline$>2.5$ & 8 \\
\hline
\end{tabular}

Source: field survey, 2016

(66\%), followed by lack of modern inputs (34\%), for example lack of fertilizer and pesticides and insecticides.

\section{Major livelihood diversification strategies of households}

The survey result showed that half of the respondents (51\%) replied that sale of livestock and their products is the primary livelihood diversification strategy followed by sale of charcoal (18\%). The remaining responded that they supported their livelihood strategies either sale of fuel wood or daily labor (Table 5). Hence, it is understood that household diversifies their livelihood using different strategies.

However, the livelihood diversification strategies households used in the study area are more worsening the state of natural resources (such as sale of fuel wood and charcoal) by facilitating deforestation that aggravates
Table 4 Attributes of impact of land degradation on livelihood

\begin{tabular}{lc}
\hline Attributes & Number of respondents \\
\hline land degradation has impact on livelihood & 100 \\
Yes & - \\
No & 11 \\
Ways of impact of land degradation on livelihood \\
Reduction in crop yield & 6 \\
Reduction in livestock production & 83 \\
Both & 90 \\
Extent of land degradation impact on livelihood \\
Serious & 10 \\
Noticeable & - \\
Negligible & 66 \\
Reason for decline in crop production & - \\
Loss in soil fertility & 34 \\
Shortage of rain & \\
Lack modern inputs
\end{tabular}

Source: field survey, 2016

land degradation. So other strategies have to be designed by concerned bodies by giving households training to shift to other non-farm strategies which help rehabilitate and conserve the surrounding natural resource.

Some of the institutional support to households to diversify their livelihood is financial support using microfinance institutions and traditional associations. This helps to shift to other livelihood diversification strategies than natural resource deforestation. Therefore, $54 \%$ of the farmer household reported that they can use different livelihood diversification strategies if they could get financial debt from microfinance institutions (such as Amhara credit and saving institution). The remaining significant number of farmer households (46\%) stated that they will shift to other livelihood diversification strategies other than natural resource deforestation if they could get training and support to form traditional associations such as Idir and Equb which help to generate their own income through supporting each other.

Table 5 Livelihood diversification strategy of households

\begin{tabular}{lll}
\hline Strategies & Frequency & Percentage \\
\hline Sale of livestock and their products & 51 & 51 \\
Sale of fuel wood & 17 & 17 \\
Sale of charcoal & 18 & 18 \\
Daily labor & 14 & 14 \\
Others & - & - \\
Total & 100 & 100
\end{tabular}

Source: field survey, 2016 
Factors influencing income diversification of households for livelihood

Although this study was conducted in Northwest Ethiopia taking a district and a peasant association as case study areas, it aims at the goal of explaining the factors influencing income diversification of households for their livelihood.

\section{Correlation and binary logistic results}

Tables 6 and 7 provide the results of the correlation and the binary logistic regressions respectively. The correlation matrix indicated that there is no multicollinearity problem since none of the explanatory variables are strongly correlated with each other (Table 6).

The results show that gender is a statistically significant $(P<.01)$ variable and is positively associated (Table 6) with income diversification $(r=.3)$. Age is found out to have a statistically significant $(P<.01)$ influence on income diversification (Table 7 ). This is also ascertained in the correlation matrix that showed positive association $(r=.1)$ between the age of household head and income diversification for livelihood (Table 6). Age is related to individual's knowledge and experience (Maser 2011), and this results in positive perception towards income diversification for their livelihood. Marital status on the other hand is not statistically significant though it has a positive relation with income diversification for livelihood as revealed both in regression results and correlation matrix (Tables 6 and 7).

Educational level is a statistically significant $(P<.05)$ variable (Table 7) and positively associated $(r=.1)$ with income diversification of households for their livelihood (Table 6). The finding reveals that those with better education are more willing to participate in income diversification for their livelihood more than the uneducated.

Landholding size is statistically significant (Table 7) at $5 \%$ level of significance. Since the average landholding size

Table 6 Correlation matrix of explanatory variables with response variable $(N=100)$

\begin{tabular}{|c|c|c|c|c|c|c|c|}
\hline Variables & INCM & GEN & AGE & EDUCL & LHS & FMS & MRS \\
\hline INCM & 1 & & & & & & \\
\hline$G E N^{* *}$ & .032 & 1 & & & & & \\
\hline$A G E^{* *}$ & .065 & .37 & 1 & & & & \\
\hline EDUCL* & .133 & .580 & .413 & 1 & & & \\
\hline $\mathrm{LHS}^{* *}$ & .007 & .261 & .027 & .344 & 1 & & \\
\hline FMS $^{* *}$ & .278 & .120 & .128 & .419 & .160 & 1 & \\
\hline MRS & .213 & .216 & .265 & .408 & .323 & .408 & 1 \\
\hline
\end{tabular}

Source: Survey results, 2016

INCM income of household, GEN gender of household head, EDUCL

educational level of household head, LHS landholding size of household head,

FMS family size of household, MRS marital status of household head

${ }^{*}$ Correlation is significant at $P<0.05$

${ }^{* *}$ Correlation is significant at $P<0.01$
Table 7 Results of binary logistic regression (forward conditional) model showing factors affecting income diversification for livelihood $(N=100)$

\begin{tabular}{llllll}
\hline Explanatory variables & $B$ & S.E. & df & Sig $(p)$ & Exp $(B)$ \\
\hline GED & 1.525 & .265 & 1 & $.00^{* *}$ & .292 \\
AGE & .462 & .413 & 1 & $.010^{* *}$ & .159 \\
EDUCL & .064 & .027 & 1 & $.030^{*}$ & 1.046 \\
LHS & .351 & .393 & 1 & $.012^{* *}$ & 1.394 \\
FMS & .659 & .257 & 1 & $.010^{* *}$ & 1.933 \\
MRS & .490 & .252 & 1 & .075 & 1.133 \\
Constant & 4.613 & .918 & 1 & $.001^{* *}$ & 1.54
\end{tabular}

Variables: GED; AGE; EDUCL; LHS; FMS; MRS. PGIDP -2 Log likelihood function $=57.66 ; X^{2}=31.027 ; \mathrm{df}=1 ;$ constant $=4.613 ;$ Cox and Snell $R$ square $=.572$;

Nagelkerke $R$ square $=.772$. Source: Survey result, 2016

$* * P<.01$

$* P<.05$

with greater than 0.5 ha is coded 1 and landholding size less than 0.5 ha is coded 0 , the positive association indicates that income diversification for livelihood is positive as the landholding size declines, because when landholding size increases, the farmer may not get extra time and labor to participate in other non-farm activities.

The binary logistic regression results show that family size is a statistically significant $(P<.01)$ variable (Table 7$)$ and is positively associated with income diversification for livelihood ( $r=.3$; Table 6$)$. The average family size for a household at national level is 4.6 (CSA 2016). It is evident, when the number of members of the family size increases, there may be a surplus of labor who can participate in different types of non-farm activities which help in income diversification for the livelihood of households.

\section{Discussion}

\section{Consequences of land degradation}

Poor land-use practices and population pressure are the major drivers of land degradation in Ethiopia (Berry 2003; Genanew and Alemu 2012). Tengberg and Torheim (2007) stated that high population pressure, especially in the highland, has led to a decline in arable area, which in turn led to agricultural encroachment onto marginal areas. Several other factors contribute to the unsustainable land management in Ethiopia. Berry (2003) also listed out that the patterns of land ownership and government control, low levels of investment in agriculture and animal husbandry, poor rural infrastructure and markets, and low levels of technology are the underlying causes of land degradation. Policy failures and lack of capacity to implement government interventions also contribute to land and other resource degradation (The Global Mechanism 2007; Wagayehu 2003; Zeleke 2010).

The economic consequence of land degradation for individual farmers and the country as a whole is high 
(Barbier and Hochard 2016). Hence, it led to the reduction of income for the farmers and GDP for the country. Production loss is the other consequence of land degradation. Hence, production loss can be computed as: [production loss $=$ production from non degraded land production from degraded land with the same inputs and management]. In line with this, Amsalu and DeGraaff (2007) has categorized the effects of land degradation as non-economic and economic. Some researchers (Duraiappah 1998; Peprah 2014) pointed out that loss in water resources, loss in livestock production, unemployment and out-migration, shortage of food and malnutrition, and lack of firewood and building materials are some of the economic and non-economic consequences. Low (2013) indicated that economic consequences are also too high and can be divided into three main categories: direct impacts (which affect the land users that cause degradation), indirect impacts (which can affect people far away from where the degradation occurs), and economy-wide impacts (in which the sum of these initial costs is increased by the "multiplier effect" owing to complex links with other economic sectors).

In the case of unemployment and out-migration, Ethiopia may stand number one in Africa to witness the power of land degradation deriving people out of their homes (Gedion 2001; Amsalu and DeGraaff 2007). Soil erosion was estimated to have cost nearly 40 million birr in 1990 in lost agricultural production while the cost of burning dung and crop residues as fuel was nearly 650 million birr (EPA 1997). In addition to this, Ethiopia has been losing 6-9\% of its GNP due to deforestation (EPA 1997; MoARD 2007).

One of the possible ways of improving the extent of the land degradation problem could be that improving the impact of interventions so far made both by the government and the international community, the country needs to revisit shortcomings (in existing strategies, projects and programs) that hamper sustainable land management and development using watershed management. Efforts should also be made to identify gaps and opportunities in existing (technical) knowledge as well as in policy and institutional factors that limit or facilitate the implementation of technical remedies.

\section{Interlink between land degradation and livelihood}

Land degradation and livelihood of farmers are pervasive and interconnected problems in Ethiopia (Amsalu et al. 2007). The prolonged effect of land degradation has resulted in erratic rainfall causing severe droughts at irregular intervals, and these droughts threaten the lives and livelihoods of millions of people (Nwokoro and Chima 2017). Drought caused by erratic rainfall brings incapability of farmers to acquire food and hence causes extreme food crises. Land degradation in the form of soil erosion and nutrient depletion affects households' production and investment decision. Soil erosion affects soil depth, which in turn affects yields and output in the following years that have a direct impact on income and welfare (Holden and Shiferaw 2004).

Scholars such as Gebreselassie et al. (2016) pointed out that due to land shortage and lack of alternative livelihoods, farmers cultivate lands that have slopes more than $60 \%$ with shallow and stony soils prone to erosion. Slopes more than $30 \%$ should not normally be used for agricultural purposes, but rather allocated to natural vegetation or forestry. However, in Ethiopia, there is no land-use policy that prohibits farmers from using such lands, and thus, more and more marginal lands are cultivated (Eyasu 2003).

According to Tilahun (2002), a direct link between land degradation and rural livelihood was drawn mainly through three pathways. The first pathway is that the decline in soil fertility as a result of land degradation decreases farm productivity and income. As crop or livestock production is the major source of household income for rural areas, the decline in soil fertility, through nutrient depletion and poor soil- and waterholding capacity, affects the on-farm income significantly. The second path is the decline in soil fertility affecting the productivity of labor. This is because a degraded land requires much more labor that competes with off-farm income of the households. The last pathway is that land degradation reduces the underground and aboveground biodiversity of the system, which, in turn, affects the biochemical process of the land and the vegetation cover of the land.

Moreover, the current level of poverty is further aggravated by the reduced productivity of the soil which is caused by unabated land degradation in the country (Zeleke 2000). This forces the people to live under vicious circle of poverty with one aggravating the other. To this end, the link between land degradation and livelihood indicate that land degradation and food insecurity are closely interconnected problems. Therefore, measures or strategies to reverse land degradation help in improving livelihood security status of a nation (Wiebe 2002).

The linkages between livelihoods, land use, and the environment generally point to the degradation of the environment leading to reduced environmental services and ecosystem functions. There is no indication that the system is self-regulating in this respect. Positive interventions will be needed to maintain ecosystem integrity. This is not only to maintain rural livelihoods but also to support other life forms. It is not simply a question of providing protected areas but also policies and practices that enhance the environmental function and livelihood benefits of land need to be developed and promoted (Soini 2006). 


\section{Theoretical concepts of livelihood}

Livelihood is defined by different researchers in different ways. However, the most agreed definition by DFID (2000) states that "A livelihood comprises the capabilities, assets (including both material and social resources) and activities required for a means of living. A livelihood is sustainable when it can cope with and recover from stresses and shocks maintain or enhance its capabilities and assets, while not undermining the natural resource base."

Sustainable livelihood thinking is inspired by the work of Robert Chambers in the 1980s and has been further developed by Chambers, Conway, and others in the 1990s (DFID 2000). The sustainable livelihood framework is a tool for development work, by highlighting how to understand, analyze, and describe the main factors that affect the livelihoods of the poor people (Fig. 2).

The framework also emphasizes the principle that there has to be a strong link between macro- and micropolitics, since these are interdependent. The macropolitics is responsible for the main structures and processes in an area, and the poor have to adapt and try to enhance their livelihoods through these. The last basic principle is that development has to have a long-term focus-it is important that the way we develop an area now will make it sustainable in the future as well (World Bank 2007).

Livelihoods strategies are the way that people act in order to achieve their desired livelihood. The access that people have to different kinds of assets affects the strategies that they employ, and the structures and processes in a given society also create possibilities and constraints on the strategies that people are able to use (Ellis 2000a).
Livelihood outcomes are the achievements of people's livelihood strategies (Lestrelin and Giordano 2007). However, outcomes are to be described by the local people themselves, since these include much more than income. For outsiders, it can be difficult to understand what people are seeking and why because this is often influenced by culture, local norms, and values (MoFED 2008). The concept of livelihood diversification is defined as "the process by which rural households construct an increasingly diverse portfolio of activities and assets in order to survive and to improve their standard of living" (Ellis 2000b). Thus, livelihood diversification is an important strategy for ensuring household livelihood security (Ellis 2000c).

According to Soini (2006), livelihoods are sustained and improved by new commodities from efficient land use. A limited resource also leads to differentiation of livelihoods due to unequal access to land and natural resources. Gessese (2018) also mentioned when the cultivation of land cannot support livelihoods, off-farm income becomes crucial. Land use has been considered the most important factor that influences the livelihood of rural communities. Understanding livelihood and land degradation interactions in the highlands of Ethiopia is highly relevant in any attempts to find solutions for sustainable land management development in the region. Rural livelihood practices largely depend on continued productive capacity of the land and adequate water resources to sustain harvestable yields.

\section{Conclusions}

The major drivers of land degradation are both natural and anthropogenic. The serious impact of land degradation on

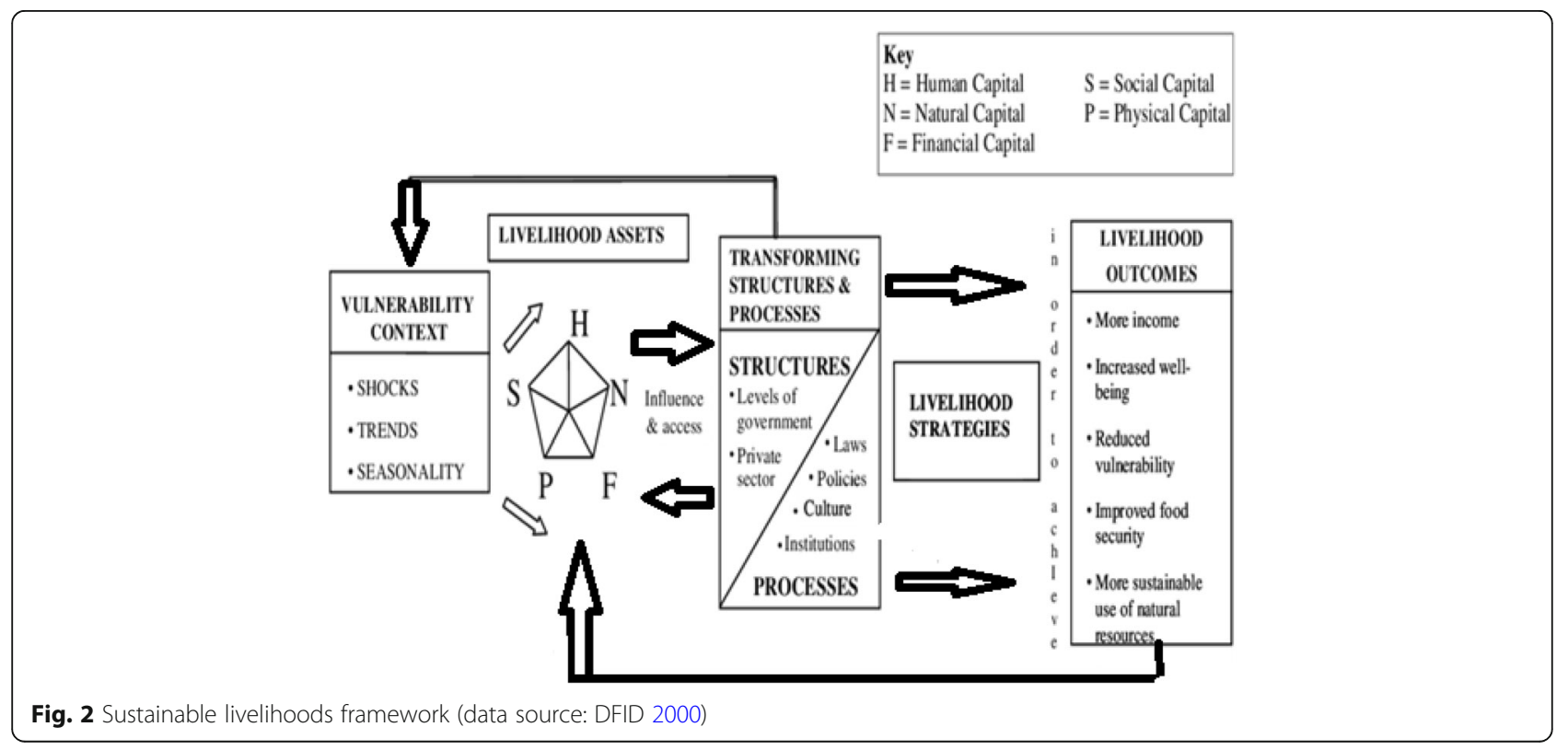


the livelihood of rural communities is observed both in the reduction of crop yield and livestock production. Land degradation and livelihood of rural communities in the study area are interlinked with each other. Since the livelihood of rural communities in the study area is strongly tied with land resources, the degradation of land directly affects their livelihood. They use selling of livestock as the coping mechanism to reduce the problem of food shortage. Land degradation and livelihood nexus should entail mobilizing resources, experts, and the community at large. It is imperative to assess the economic implications of land degradation together with the costs that need to be incurred to remedy the situation. Policy makers need to be committed to making a difference and embarking on natural resources management instead of merely rehabilitating degraded lands.

\section{Abbreviations \\ CSA: Central Statistical Agency; CWAO: Chilga Woreda Agricultural Office; EPA: Environmental Protection Agency; FGD: Focus group discussion; MoARD: Ministry of Agriculture and Rural Development; MoFED: Ministry of} Finance and Economic Development; NMA: National Meteorological Agency

\section{Acknowledgements}

Financial support is given by University of Gondar for the second author for his MA thesis. We thank also the data collectors and sample respondents.

\section{Funding}

This research is supported by the University of Gondar for the partial fulfillment of Master's thesis.

\section{Authors' contributions}

YM mainly collected the data and did the preliminary analysis and some interpretation. KG mainly designed this work and revised the paper totally. Both authors read and approved the final manuscript.

\section{Ethics approval and consent to participate}

Not applicable.

\section{Consent for publication}

Not applicable.

\section{Competing interests}

The authors declare that they have no competing interests.

\section{Publisher's Note}

Springer Nature remains neutral with regard to jurisdictional claims in published maps and institutional affiliations.

\section{Author details}

${ }^{1}$ Department of Geography and Environmental Studies, University of Gondar, P.O. Box 196, Gondar, Ethiopia. ${ }^{2}$ Natural Resource and Environmental Management, Chilga District Agricultural Office, Aykel, Ethiopia.

Received: 27 June 2018 Accepted: 24 September 2018 Published online: 04 October 2018

\section{References}

Amsalu, A. Caring for the land best practices in soil and water conservation in Beressa watershed highlands of Ethiopia. Tropical resource management paper; No.76 (2006). The Netherlands: Wageninger University; 2006.

Amsalu A, de Graaff J. Farmers' views of soil erosion problems and their conservation knowledge at Beressa watershed, central highlands of Ethiopia. Agric Hum Values. 2006;23(1):99-108.
Amsalu A, De Graaff J. Determinants of adoption and continued use of stone terraces for soil and water conservation in an Ethiopian highland watershed. Ecol Econ. 2007;61(2-3):294-302.

Amsalu A, Stroosnijder L, de Graaff J. Long-term dynamics in land resource use and the driving forces in the Beressa watershed, highlands of Ethiopia. J Environ Manag. 2007;83(4):448-59.

Barbier EB, Hochard JP. Does land degradation increase poverty in developing countries? PLoS One. 2016;11(5):e0152973.

Berry, L. (2003). Land degradation in Ethiopia: its extent and impact. A study commissioned by the GM with WB support.

Berry, L. (2009). Land degradation in Ethiopia: its extent and impact. New York: Global Mechanism and World Bank.

Bewket W. Land degradation and farmers' acceptance and adoption of conservation technologies in the Digil water shade, northwestern highlands of Ethiopia. Addis Ababa: OSSREA, social science research report series no 29; 2003.

Bizuayehu T, Gezahegn A, Yigezu A, Jabbar M, Paulos D. Nature and causes of land degradation in the Oromiya region: socio- economic and policy research working paper 36. Addis Ababa: International Livestock Research Institute; 2002.

Bojö J, Cassells D. Land degradation and rehabilitation in Ethiopia: a reassessment. AFTES Working Paper, No. 17. New York: World Bank; 1995.

CSA. Statistical abstract. Ethiopia: Addis Ababa; 2016.

CSA. Statistical abstract. Ethiopia: Addis Ababa; 2017.

CWAO, Chilga district annual report, Unpublished report; 2015

Darkoh M. Land degradation and soil conservation in eastern and southern Africa; a research agenda. Desertification Control Bull. 1993;22:60-8.

DFID.Framework introduction. Sustainale livelihoods guidance sheets. 2000 available at: http://www.ids.ac.uk/livelihoods.

Duraiappah AK. Poverty and environmental degradation: a review and analysis of the nexus. World Dev. 1998;26(12):2169-79.

Ellis F. The determinants of rural livelihood diversification in developing countries. J Agric Econ. 2000a;51(2):289-302.

Ellis F. Rural livelihoods and diversity in developing countries. Oxford: Oxford university press; 2000b.

Ellis $F$. The determinants of rural livelihood diversification in developing countries J Agric Econ. 2000c;51(2):289-302.

EPA. The conservation strategy of Ethiopia, volume I. The resource base, its utilization and planning for sustainability. Addis Ababa: EPA; 1997

Eyasu, National assessment on environmental roles of agriculture in Ethiopia, Unpublished research report; 2003.

FAO (1986). Highlands reclamation study. Final report, volume I and II. Food and agricultural organization, Rome

Gashaw T, Bantider A, G/Silassie H. Land degradation in Ethiopia: causes, impacts and rehabilitation techniques. J Environ Earth Sci. 2014;4:9.

Gebreselassie S, Kirui OK, Mirzabaev A. Economics of land degradation and improvement in Ethiopia. In: Economics of land degradation and improvement-a global assessment for sustainable development. Cham: Springer; 2016. p. 401-30.

Gedion A. Assessment of the environmental policy of Ethiopia. In: Tadesse Z, editor. Environment and Development in Ethiopia proceedings of the symposium of the forum for social studies Addis Ababa. Addis Ababa: forum for social studies; 2001.

Genanew BW, Alemu M. Investments in land conservation in the Ethiopian highlands: a household plot-level analysis of the roles of poverty, tenure security, and market incentives. Int J Econ Financ. 2012;4(6). https://doi.org/ 10.5539/ijef.v4n6p32. Accessed 31 May 2015.

Gessese BH. Impact of land use/land cover change on rural communities' livelihood of Ethiopia. J Ecol Environ Sci. 2018;6:1.

Hammad AA, Tumeizi A. Land degradation: socioeconomic and environmental causes and consequences in the eastern Mediterranean. Land Degrad Dev. 2012;2:216-26.

Holden S, Shiferaw B. Land degradation, drought and food security in a lessfavoured area in the Ethiopian highlands: a bio-economic model with market imperfections. Agric Econ. 2004;30(1):31-49.

Hurni $\mathrm{H}$. Degradation and conservation of soil resources in the Ethiopian highlands. In: Messerli B, Hurni H, editors. African mountains and highlands: problems and prospective. Marceline: walsworth press, for the African Mountains Association(AMA).; 1990. p. 51-63.

Hurni H. Land degradation, famine and land resource scenarios in Ethiopia. Cambridge: Cambridge university press; 1993

Kothari CR. Research methodology. 2nd ed. India: University of Rajasthan; 2004. 
Lestrelin G, Giordano M. Upland development policy, livelihood change and land degradation: interactions from a Laotian village. Land Degrad Dev. 2007;18: 55-76.

Limeneh M. Effects of land use change on soil quality and native flora degradation and restoration in the highlands of Ethiopia: implication for sustainable land management. Ph.D Thesis. Uppsala: Swedish university of agricultural science; 2004.

Low, P.S. (ed) Economic and social impacts of desertification, land degradation and drought. White Paper I. UNCCD 2nd Scientific Conference, prepared with the contributions of an international group of scientists. 2013. Available from: https://profiles.uonbi.ac.ke/jmariara/files/unccd_white_paper_1.pdf. Accessed 26 Mar 2013.

Maser C. Social-environmental planning: the design interface between every forest and every city. London: CRC Press, Taylor, and Francis Group; 2011.

MoARD. Thematic papers on land degradation in Ethiopia. New York: World Bank Publication; 2007.

MoARD. Ethiopia's agricultural sector: policy and investment framework (PIF) 2010-2020. Draft Final Rep. 2010. Available from: http://library.stic.et/ documents/3049/611723/Ethiopian+agricultural+sector+policy+framework. pdf/3539fc4f-77d4-2b54-6bc9-7a44b7caaa99?version=1.0. Accessed 29 Apr 2017.

MoFED, (2008). Dynamics of growth and poverty in Ethiopia (1995/96-2004/05), Addis Ababa: Ethiopia Poverty-Final 2009pdf. Accessed 15 June 2011.

Nachtergaele F, Petri M, Biancalani R, Van LG, VanVelthuizen H. Global land degradation information system (GLADIS). Beta Version. An information database for land degradation assessment at global level, Land degradation assessment in dry lands technical report, no. 17. Rome: FAO; 2010.

NMA, (2015). National meteorological report, Addis Ababa, Ethiopia.

Nwokoro CV, Chima FO. Impact of environmental degradation on agricultural production and poverty in rural Nigeria. Am Int J Contemp Res. 2017;7:2.

Peprah K. Poverty and land degradation nexus: the case of Asunafo, Ghana. Int J Sci Res. 2014;3(4):483-9.

Pricope NG, Husak G, Lopez-Carr D, Funk C, Joel Michaelsen J. The climatepopulation nexus in the East African Horn: emerging degradation trends in rangeland and pastoral livelihood zones. Glob Environ Chang. 2013;23:152541.

Reddy VR. Land degradation in India: extent, cost and determinants. Econ Polit Econ. 2003;38:44

Shiferaw B, Holden S. Resource degradation and adoption of land conservation technologies in the Ethiopian Highlands: A case study in Andit Tid, North Shewa. Agric Econ. 1998;(18):233-247.

Sivakumar MVK, Ndiangui N, editors. Climate and land degradation. Berlin Heidelberg: Springer-Verlag; 2007.

Soini, E. Livelihood, land use and environment interactions in the highlands of East Africa. PhD Dissertation, Helsinki: University of Helsinki; 2006.

Sonneveld BG. Land under pressure: The impact of water erosion on food production in Ethiopia. Netherlands: Shaker Publishing (PhD dissertation); 2002.

Tengberg A, Torheim SIB. The role of land degradation in the agriculture and environment nexus. In: Climate and land degradation. Berlin, Heidelberg: Springer; 2007. p. 267-83.

The Global Mechanism. Increasing finance for sustainable land management. The global mechanism of the UNCCD—Via Paolo di Dono 44-00142 Rome. Italy: The Global Mechanism; 2007. Available online at http://www.carfu.org/ wpcontent/uploads/2015/01/Global-Mechanism-of-UNCDD-morocco_e-1.pdf. Accessed 21 May 2016

Tilahun A. Opportunities and challenges in reversing land degradation: The regional experience. In: Proceedings of a conference on: natural resources degradation and environmental concerns in the Amhara national regional state, Ethiopia impact on food security. Bahir Dar: ESSS; 2002. p. 173-83.

Wagayehu B. Economics of soil and water conservation: Theory and empirical application to subsistence farming in the eastern Ethiopian highlands. Uppsala: Doctoral thesis, Swedish University of Agricultural Sciences; 2003.

Wiebe K. Linking land quality, agricultural productivity, and food security /AER823: USDA/ Economic Research Service; 2002. https://www.ers.usda.gov/ publications/pub-details/?pubid=41575. Accessed 21 Feb 2016.

World Bank. World development report 2008: agriculture for development. Washington, DC: World Bank; 2007.

World Food Program (WFP). Ethiopia country program. Addis Ababa: World Food Program (WFP); 2005.
Zeleke G. Landscape dynamics and soil erosion process modeling in the Northwestern Ethiopian highlands. Ph.D. dissertation. Berne: African studies series A16, Geographica Bernengia; 2000.

Zeleke G. A study on mountain externalities in Ethiopia. Final report, FAO Sustainable Agriculture and Sustainable Development, Mountain Policy Project, Addis Ababa. 2010.
Ready to submit your research? Choose BMC and benefit from:

- fast, convenient online submission

- thorough peer review by experienced researchers in your field

- rapid publication on acceptance

- support for research data, including large and complex data types

- gold Open Access which fosters wider collaboration and increased citations

- maximum visibility for your research: over $100 \mathrm{M}$ website views per year

At BMC, research is always in progress.

Learn more biomedcentral.com/submissions 